\title{
Stereospecific Anionic Polymerization of $\alpha$-Substituted Acrylates Bearing Acetylenic Groups
}

\author{
Hideo BARAKI, Shigeki HabaUe, and Yoshio Окамото ${ }^{\dagger}$ \\ Department of Applied Chemistry, Graduate School of Engineering, \\ Nagoya University, Furo-cho, Chikusa-ku, Nagoya 464-8603, Japan
}

(Received December 25, 2000; Accepted March 3, 2001)

\begin{abstract}
KEY WORDS Stereospecific Polymerization / $\alpha$-(Propargyl)acrylate / Acetylene / Isotactic Polymer / Anionic Polymerization / Reactive Polymer /
\end{abstract}

The design and stereospecific synthesis of polymers possessing a variety of functional groups are attractive and important for developing novel functional materials. The stereospecific polymerization of $\alpha$-substituted acrylates, having two different types of functional groups on an olefin, is particularly interesting, because the polymer has a characteristic structure with arranged functional groups on the main chain of the polyacrylate. Although many studies have been reported on the polymerization of $\alpha$-substituted acrylates by the radical and anionic methods, ${ }^{1}$ no data are available on the polymerization of $\alpha$-substituted acrylates bearing a propargyl group at their $\alpha$-position. In addition, the acetylenic linkage is convenient for further transformation to other various functional groups. Therefore, the synthesis of stereoregular polymers with acetylenic groups as a side chain may provide a useful methodology for constructing a novel function.

In general, the polymerizability of $\alpha$-substituted acrylates is very sensitive to the bulkiness of the $\alpha$ substituents. For example, the radical and anionic polymerizations of acrylates with bulky $\alpha$-substituents, such as $\alpha$-isopropyl- and $\alpha$-sec-butylacrylates, do not afford a polymer, ${ }^{2}$ whereas the anionic polymerization of $\alpha$-ethyl- and $\alpha$-n-propylacrylates in toluene at $0^{\circ} \mathrm{C}$ gave isotactic polymers in low yields. ${ }^{3}$ Recently, we reported that the anionic polymerization of $\alpha$-substituted acrylates bearing various polar groups, ${ }^{4,5}$ such as alkoxymethyl and aminomethyl groups with lithium reagents proceeds in good yields to afford highly isotactic polymers. The main factor in the stereocontrol should be due to the intra- and intermolecular coordination of the countercation $\left(\mathrm{Li}^{+}\right)$to the polar groups at the $\alpha$-position. Therefore, the design of $\alpha$-substituents is important for the effective and controlled synthesis of $\operatorname{poly}(\alpha-$ substituted acrylate)s.

Here, we report that the polymerization of novel $\alpha$ substituted acrylates having an acetylenic group, such as ethyl $\alpha$-(3-trimethylsilyl-2-propynyl)acrylate (1), ethyl $\quad \alpha$-(3-phenyl-2-propynyl)acrylate $\quad(2), \quad \alpha$-[3-(2methoxylphenyl)-2-propynyl]acrylate (3), ethyl $\alpha-(4,4-$ dimethyl-2-pentynyl)acrylate (4), ethyl $\alpha$-(4-methoxy-2butynyl)acrylate (5), and ethyl $\alpha$-(4-dimethylamino-2butynyl)acrylate (6). The effects of various acetylenic

\footnotetext{
${ }^{\dagger}$ To whom all correspondence should be addressed.
}

groups on the reactivity and stereoregularity in the anionic and radical polymerizations were examined. The obtained poly(1) was easily converted into poly[ethyl $\alpha$ (propargyl)acrylate] (poly(7)), which has a reactive acetylene unit in the side chain.

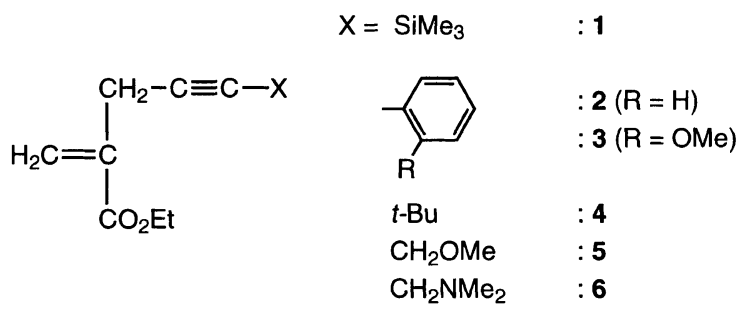

\section{EXPERIMENTAL}

\section{Measurements}

${ }^{1} \mathrm{H}$ and ${ }^{13} \mathrm{C}$ NMR spectra were measured on a Gemini$2000\left(400 \mathrm{MHz}\right.$ for $\left.{ }^{1} \mathrm{H}\right)$ or Unity-Inova-500 $(500 \mathrm{MHz}$ for ${ }^{1} \mathrm{H}$ ) spectrometer in $\mathrm{CDCl}_{3}$. Chemical shifts were reported in parts per million (ppm) with tetramethylsilane (TMS, $0 \mathrm{ppm}$ ) and $\mathrm{CDCl}_{3}(77.0 \mathrm{ppm})$ as the internal standards for ${ }^{1} \mathrm{H}$ and ${ }^{13} \mathrm{C} \mathrm{NMR}$, respectively. Infrared (IR) spectra were recorded on a JACSO FT/IR-620 spectrometer. Ultraviolet (UV) absorption spectra were recorded on a JASCO V-570 spectrometer. Size exclusion chromatographic (SEC) analysis was performed on Shodex System-21 SEC equipped with Shodex UV-41 and a Shodex RI-71 S detectors using Shodex KF-830 and KF$806 \mathrm{~F}$ columns connected in series and tetrahydrofuran (THF) was used as the eluent. Calibration was performed using standard polystyrenes. Solvents and reagents were purified or prepared as previously reported. ${ }^{4,5}$

\section{Monomer Synthesis}

Ethyl $\alpha$-(3-trimethylsilyl-2-propynyl)acrylate (1): To a solution of $8.2 \mathrm{~mL}(58 \mathrm{mmol})$ of trimethylsilylacetylene in $80 \mathrm{~mL}$ of THF was added dropwise $36 \mathrm{~mL}$ of $n$-BuLi (58 mmol, $1.6 \mathrm{M}$ in $n$-hexane) at $-78^{\circ} \mathrm{C}$. The reaction mixture was stirred for $0.5 \mathrm{~h}$ at $-78^{\circ} \mathrm{C}$ and then a solution of ethyl $\alpha$-(bromomethyl)acrylate ${ }^{6}$ in $30 \mathrm{~mL}$ of THF $(11.2 \mathrm{~g}, 58.0 \mathrm{mmol})$ was added dropwise. The reaction mixture was warmed to room temperature and stirred 
for further $5 \mathrm{~h}$. The reaction was quenched by treatment with $10 \mathrm{~mL}$ of water and the solvents were removed under reduced pressure. The residue was dissolved in $150 \mathrm{~mL}$ of dichloromethane, washed with water and dried over anhydrous $\mathrm{MgSO}_{4}$. After evaporation of the solvents, the obtained crude product was purified by column chromatography on silica gel (hexane/diethyl ether $=3 / 1, \mathrm{v} / \mathrm{v})$ and distillation $\left(51.5-52^{\circ} \mathrm{C} / 0.25 \mathrm{mmHg}\right)$ to afford 1. Yield $3.6 \mathrm{~g} \mathrm{(30 \% ),} \mathrm{colorless} \mathrm{liquid;}{ }^{1} \mathrm{H}$ NMR (400 $\mathrm{MHz} \mathrm{CDCl}_{3}$ ): $\delta 0.18\left(\mathrm{~s}, 9 \mathrm{H}, \mathrm{SiCH}_{3}\right), 1.30(\mathrm{t}, 3 \mathrm{H}, J=7.2$ $\left.\mathrm{Hz}, \mathrm{CH}_{3}\right), 3.27\left(\mathrm{~m}, 2 \mathrm{H}, \mathrm{CH}_{2}\right), 4.22(\mathrm{q}, 2 \mathrm{H}, J=7.2 \mathrm{~Hz}$, $\left.\mathrm{OCH}_{2}\right), 6.02(\mathrm{~m}, 1 \mathrm{H}$, vinyl), 6.33 ( $\mathrm{m}, 1 \mathrm{H}$, vinyl); IR (neat, $\mathrm{cm}^{-1}$ ): 2961, 2181, 1718, 1632, 1415, 1275, 1251, 1139, 1037, 843; Elemental analysis. Found: $\mathrm{C} 62.81 \%, \mathrm{H}$ 8.60\%. Calcd for $\mathrm{C}_{11} \mathrm{H}_{18} \mathrm{O}_{2} \mathrm{Si}$ : C $62.81 \%$, $\mathrm{H} 8.63 \%$.

Monomers 2-6 were synthesized by a similar procedure using the corresponding acetylenes.

Ethyl $\alpha$-(3-phenyl-2-propynyl)acrylate (2): Yield 32\%; bp $104-105.5^{\circ} \mathrm{C} / 0.3 \mathrm{mmHg} ;{ }^{1} \mathrm{H}$ NMR (400 $\left.\mathrm{MHz}, \mathrm{CDCl}_{3}\right)$ : $\delta 1.32\left(\mathrm{t}, 3 \mathrm{H}, J=7.2 \mathrm{~Hz}, \mathrm{CH}_{3}\right), 3.47\left(\mathrm{~m}, 2 \mathrm{H}, \mathrm{CH}_{2}\right), 4.25$ (q, $2 \mathrm{H}, J=7.2 \mathrm{~Hz}, \mathrm{OCH}_{2}$ ), $6.09(\mathrm{~m}, 1 \mathrm{H}$, vinyl), $6.36(\mathrm{~m}$, $1 \mathrm{H}$, vinyl), $7.30(\mathrm{~m}, 3 \mathrm{H}$, aromatic), $7.43(\mathrm{~m}, 2 \mathrm{H}$, aromatic); IR (neat, $\mathrm{cm}^{-1}$ ): 2981, 1715, 1636, 1490, 1286, 1251, 1135, 1029, 952; Elemental analysis. Found: C $78.48 \%, \mathrm{H}$ 6.69\%. Calcd for $\mathrm{C}_{14} \mathrm{H}_{14} \mathrm{O}_{2}: \mathrm{C} 78.48 \%, \mathrm{H}$ $6.59 \%$.

Ethyl $\alpha$-[3-(2-methoxyphenyl)-2-propynyl]acrylate (3): Yield 67\%; ${ }^{1} \mathrm{H}$ NMR (400 MHz, $\mathrm{CDCl}_{3}$ ): $\delta 1.32(\mathrm{t}, 3 \mathrm{H}, J$ $\left.=7.2 \mathrm{~Hz}, \mathrm{CH}_{3}\right), 3.52\left(\mathrm{~m}, 2 \mathrm{H}, \mathrm{CH}_{2}\right), 3.88\left(\mathrm{~s}, 3 \mathrm{H}, \mathrm{OCH}_{3}\right)$, $4.24\left(\mathrm{q}, 2 \mathrm{H}, J=7.2 \mathrm{~Hz}, \mathrm{OCH}_{2}\right), 6.22(\mathrm{~m}, 1 \mathrm{H}$, vinyl), 6.39 (m, $1 \mathrm{H}$, vinyl), $6.89(\mathrm{~m}, 2 \mathrm{H}$, aromatic), $7.28(\mathrm{~m}, 2 \mathrm{H}$, aromatic), $7.41\left(\mathrm{~m}, 1 \mathrm{H}\right.$, aromatic); IR (neat, $\left.\mathrm{cm}^{-1}\right)$ : 2980 , 1716, 1636, 1493, 1257, 1137, 1025; Elemental analysis. Found: C 73.76\%, $\mathrm{H}$ 6.73\%. Calcd for $\mathrm{C}_{14} \mathrm{H}_{16} \mathrm{O}_{2}$ : C $73.75 \%, \mathrm{H} 6.60 \%$.

Ethyl $\alpha$-(4,4-dimethyl-2-pentynyl)acrylate (4): Yield $35 \%$; bp 76- $\left.78^{\circ} \mathrm{C} / 3 \mathrm{mmHg} ;{ }^{1} \mathrm{H} \mathrm{NMR} \mathrm{(400} \mathrm{MHz}, \mathrm{CDCl}_{3}\right)$ : $\delta 1.24\left(\mathrm{~s}, 9 \mathrm{H}, \mathrm{CH}_{3}\right), 1.30\left(\mathrm{t}, 3 \mathrm{H}, J=7.2 \mathrm{~Hz}, \mathrm{CH}_{3}\right), 3.12$ $\left(\mathrm{m}, 2 \mathrm{H}, \mathrm{CH}_{2}\right), 4.21\left(\mathrm{q}, 2 \mathrm{H}, J=7.2 \mathrm{~Hz}, \mathrm{OCH}_{2}\right), 6.00(\mathrm{~m}$,
$1 \mathrm{H}$, vinyl), $6.30\left(\mathrm{~m}, 1 \mathrm{H}\right.$, vinyl); IR (neat, $\mathrm{cm}^{-1}$ ): 2969 , 1717, 1635, 1476, 1362, 1262, 1136, 1028, 951; Elemental analysis. Found: $\mathrm{C} 74.05, \mathrm{H}$ 9.62. Calcd for $\mathrm{C}_{12} \mathrm{H}_{18} \mathrm{O}_{2}$ : C $74.19 \%$, H $9.34 \%$.

Ethyl $\alpha$-(4-methoxy-2-butynyl)acrylate (5): Yield 45\%; ${ }^{1} \mathrm{H} \mathrm{NMR}\left(400 \mathrm{MHz}, \mathrm{CDCl}_{3}\right): \delta 1.31(\mathrm{t}, 3 \mathrm{H}, J=7.2 \mathrm{~Hz}$, $\left.\mathrm{CH}_{3}\right), 3.28\left(\mathrm{~m}, 2 \mathrm{H}, \mathrm{CCH}_{2} \mathrm{O}\right), 3.39\left(\mathrm{~s}, 3 \mathrm{H}, \mathrm{OCH}_{3}\right), 4.14(\mathrm{~m}$, $\left.2 \mathrm{H}, \mathrm{CH}_{2}\right), 4.22$ (q, $\left.2 \mathrm{H}, J=7.2 \mathrm{~Hz}, \mathrm{OCH}_{2}\right), 6.00(\mathrm{~m}, 1 \mathrm{H}$, vi$\mathrm{nyl}$ ), $6.32\left(\mathrm{~m}, 1 \mathrm{H}\right.$, vinyl); IR (neat, $\mathrm{cm}^{-1}$ ): 2984, 1716, 1639, 1369, 1280, 1254, 1122, 1026, 952; Elemental analysis. Found: C $65.90 \%, \mathrm{H} 7.85 \%$. Calcd for $\mathrm{C}_{10} \mathrm{H}_{14} \mathrm{O}_{3}$ : C $65.91 \%$, H 7.74\%.

Ethyl $\alpha$-(4-dimethylamino-2-butynyl)acrylate $(6)$ : Yield $82 \% ;{ }^{1} \mathrm{H}$ NMR $\left(400 \mathrm{MHz} \mathrm{CDCl}_{3}\right): \delta 1.31(\mathrm{t}, 3 \mathrm{H}, J$ $\left.=7.2 \mathrm{~Hz}, \mathrm{CH}_{3}\right), 2.30\left(\mathrm{~s}, 6 \mathrm{H}, \mathrm{NCH}_{3}\right), 3.27\left(\mathrm{~m}, 4 \mathrm{H}, \mathrm{CH}_{2}\right.$ $\left.+\mathrm{CCH}_{2} \mathrm{~N}\right), 4.22\left(\mathrm{q}, 2 \mathrm{H}, J=7.2 \mathrm{~Hz}, \mathrm{OCH}_{2}\right), 6.02(\mathrm{~m}, 1 \mathrm{H}$, vinyl), $6.32\left(\mathrm{~m}, 1 \mathrm{H}\right.$, vinyl); IR (neat, $\mathrm{cm}^{-1}$ ): 2979,1716 , 1636, 1457, 1278, 1144, 1031, 952; Elemental analysis. Found: C 67.54, H 8.93, N 7.30. Calcd for $\mathrm{C}_{11} \mathrm{H}_{17} \mathrm{NO}_{2}$ : C $67.66 \%, \mathrm{H} 8.78 \%, \mathrm{~N} 7.17 \%$.

Polymerization was carried out in the same way as previously reported. ${ }^{4,5}$

\section{Synthesis of Poly[ethyl $\alpha$-(propargyl)acrylate]}

Poly(1) (80 mg) was dissolved in $2 \mathrm{~mL}$ of THF, and $0.38 \mathrm{~mL}$ of tetrabutylammonium fluoride (1.0 M in THF) was then added at $0^{\circ} \mathrm{C}$. The reaction mixture was warmed to room temperature and stirred for $12 \mathrm{~h}$. After the addition of a saturated $\mathrm{NH}_{4} \mathrm{Cl}$ aqueous solution $(5 \mathrm{~mL})$ to the reaction mixture, the products were collected by extraction with chloroform. The combined organic extracts were dried over anhydrous $\mathrm{MgSO}_{4}$ and concentrated in vacuo. The residue was dissolved in a small amount of chloroform, and precipitated in an excess amount of methanol. The polymer was then separated by centrifugation and dried in vacuo.

Table I. Radical and anionic polymerizations of $1-6^{\mathrm{a}}$

\begin{tabular}{|c|c|c|c|c|c|c|c|}
\hline \multirow{2}{*}{$\begin{array}{c}\text { Entry } \\
1\end{array}$} & \multirow{2}{*}{$\begin{array}{c}\text { Monomer } \\
\mathbf{1}\end{array}$} & \multirow{2}{*}{$\frac{\text { Initiator }}{n-\mathrm{BuLi}}$} & \multicolumn{2}{|c|}{ Conditions } & \multirow{2}{*}{$\frac{\frac{\text { Yield }^{\mathrm{b}}}{\%}}{85}$} & \multirow{2}{*}{$\frac{\frac{\bar{M}_{\mathrm{n}}{ }^{\mathrm{c}}}{\times 10^{-4}}}{4.9}$} & \multirow{2}{*}{$\frac{\bar{M}_{\mathrm{w}} / \bar{M}_{\mathrm{n}}{ }^{\mathrm{c}}}{6.7}$} \\
\hline & & & Toluene, & $-78^{\circ} \mathrm{C}, 48 \mathrm{~h}$ & & & \\
\hline 3 & $\mathbf{1}$ & AIBN & None, & $60^{\circ} \mathrm{C}, 72 \mathrm{~h}$ & 0 & - & - \\
\hline 4 & 2 & $n$-BuLi & Toluene, & $-78^{\circ} \mathrm{C}, \quad 48 \mathrm{~h}$ & 78 & 1.5 & 5.1 \\
\hline 5 & 2 & $n$-BuLi & THF, & $-78^{\circ} \mathrm{C}, 96 \mathrm{~h}$ & 41 & 0.4 & 1.5 \\
\hline 6 & 2 & AIBN & None, & $60^{\circ} \mathrm{C}, 72 \mathrm{~h}$ & 37 & 0.2 & 1.7 \\
\hline 7 & 3 & $n$-BuLi & Toluene, & $-78^{\circ} \mathrm{C}, \quad 48 \mathrm{~h}$ & 65 & 1.1 & 5.0 \\
\hline 8 & 3 & $n$-BuLi & THF, & $-78^{\circ} \mathrm{C}, 96 \mathrm{~h}$ & 5 & 0.3 & 1.3 \\
\hline 9 & 3 & AIBN & None, & $60^{\circ} \mathrm{C}, 72 \mathrm{~h}$ & 57 & 0.3 & 1.4 \\
\hline 10 & 4 & $n$-BuLi & Toluene, & $-78^{\circ} \mathrm{C}, \quad 48 \mathrm{~h}$ & 85 & 3.3 & 18.1 \\
\hline 11 & 4 & $n$-BuLi & THF, & $-78^{\circ} \mathrm{C}, 96 \mathrm{~h}$ & 10 & 0.6 & 1.8 \\
\hline 12 & 4 & AIBN & None, & $60^{\circ} \mathrm{C}, 72 \mathrm{~h}$ & 0 & - & - \\
\hline 13 & $\mathbf{5}$ & $n$-BuLi & Toluene, & $-78^{\circ} \mathrm{C}, \quad 48 \mathrm{~h}$ & $75^{\mathrm{d}}$ & 1.7 & 3.2 \\
\hline 14 & 5 & $\mathrm{Ph}_{2} \mathrm{NLi}^{-T M E D A}{ }^{\mathrm{e}}$ & Toluene, & $-78^{\circ} \mathrm{C}, \quad 48 \mathrm{~h}$ & $83^{d}$ & 0.8 & 1.7 \\
\hline 15 & 5 & $n$-BuLi & THF, & $-78^{\circ} \mathrm{C}, 96 \mathrm{~h}$ & $45^{\mathrm{d}}$ & 0.4 & 2.3 \\
\hline 17 & 6 & $n-\mathrm{BuLi}$ & Toluene, & $-78^{\circ} \mathrm{C}, \quad 48 \mathrm{~h}$ & $27^{\mathrm{d}}$ & n.d. ${ }^{f}$ & n.d. ${ }^{f}$ \\
\hline 18 & 6 & $n$-BuLi & THF, & $-78^{\circ} \mathrm{C}, 96 \mathrm{~h}$ & $26^{\mathrm{d}}$ & n.d. ${ }^{f}$ & n.d. ${ }^{f}$ \\
\hline 19 & 6 & $\mathrm{AIBN}$ & None, & $60^{\circ} \mathrm{C}, 72 \mathrm{~h}$ & 0 & - & - \\
\hline
\end{tabular}

${ }^{\mathrm{a}}$ [Monomer] / [initiator] $=20$ for anionic polymerization and 30 for radical polymerization. ${ }^{\mathrm{b}}$ Hexane-insoluble part for radical polymerization and $\mathrm{MeOH}$-insoluble part for anionic polymerization. ${ }^{\mathrm{c}}$ Determined by SEC (polystyrene standard, eluent: THF). ${ }^{\mathrm{d}} \mathrm{Hexane-insoluble}$ part, ref 7. ${ }^{\mathrm{e}} N, N, N^{\prime}, N^{\prime}$-Tetramethylehylenediamine. ${ }^{\mathrm{f}}$ Not determined. 


\section{RESULTS AND DISCUSSION}

The results of the anionic and radical polymerizations of $\mathbf{1 - 6}$ are listed in Table I. The anionic polymerization with $n$-BuLi in toluene proceeded with good yields except for 6. The obtained polymers are soluble in $\mathrm{CHCl}_{3}$ and THF. Poly(5) and poly(6) bearing ether and amino groups in the side chain, respectively, are also soluble in methanol. ${ }^{7}$ Figures 1a, 2a, 3a, and $3 \mathrm{~b}$ show the ${ }^{1} \mathrm{H}$ and ${ }^{13} \mathrm{C}$ NMR spectra of the anionically obtained polymers from 1 and 2 in toluene. The spectral patterns are simple and assigned to the polymers with a normal vinyl polymer structure as shown in the figures. The acetylenic moiety at the $\alpha$-position hardly reacts during the anionic polymerization in toluene, and the novel poly $(\alpha-$ substituted acrylate)s containing various propargyl groups in the $\alpha$-substituent were synthesized.

The anionic polymerizations in THF, however, resulted in lower yields than those in toluene. $\operatorname{Poly}(\mathbf{1})$ anionically obtained in THF appears to have a vinyl polymer structure based on the ${ }^{1} \mathrm{H}$ (Figure $1 \mathrm{~b}$ ) and ${ }^{13} \mathrm{C}$ NMR analyses. These spectra showed broader peaks than those of the polymer prepared with $n$-BuLi in toluene, suggesting that the anionic polymerization of 1 in THF proceeded in a less stereocontrolled manner than that in toluene. The anionic polymerization of 4 and 6 in THF also gave polymers with a normal vinyl polymer structure, similar to that of $\mathbf{1}$. However, the polymerization of
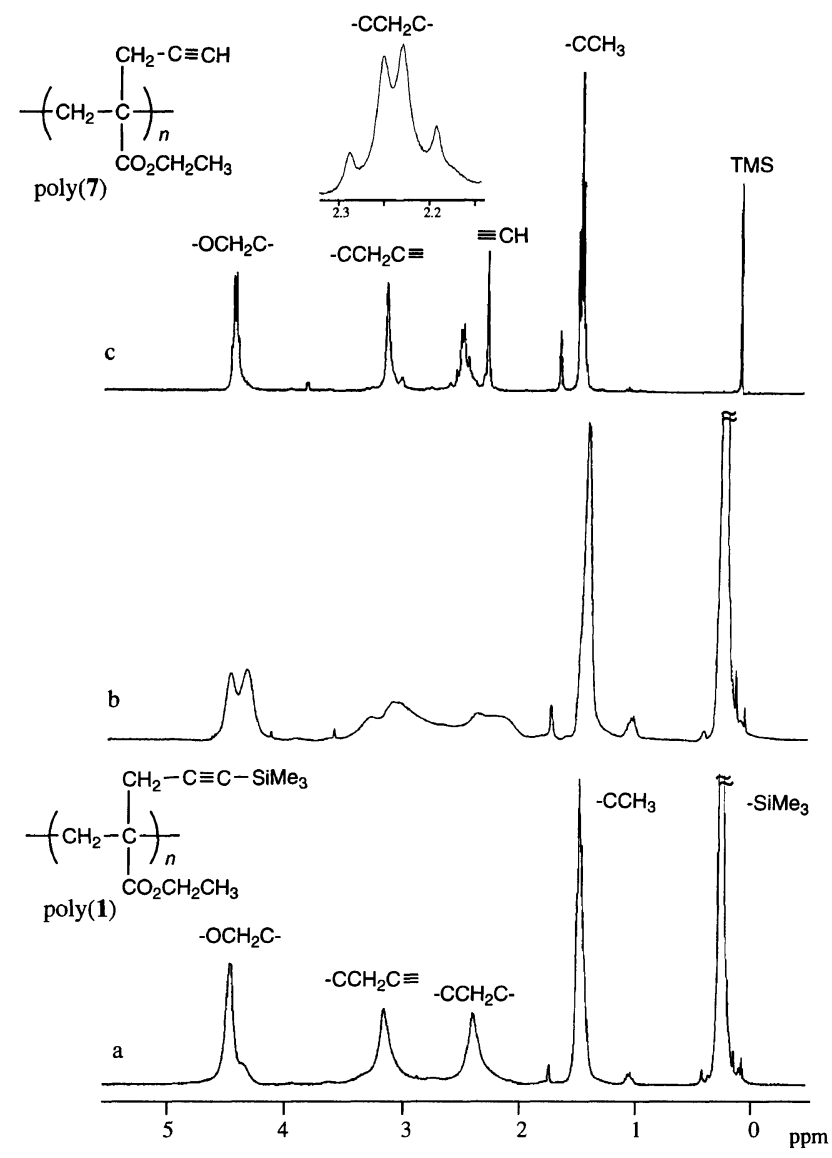

Figure 1. ${ }^{1} \mathrm{H}$ NMR spectra of $\operatorname{poly}(1)$ s obtained with $n$-BuLi in toluene (entry 1) (a), in THF (entry 2) (b), and poly(7) derived from $\operatorname{poly}(1)(\mathrm{c})\left(\right.$ measured in $\mathrm{CDCl}_{3}$ at $\left.60^{\circ} \mathrm{C}\right)$. $\mathbf{2}, \mathbf{3}$, and $\mathbf{5}$ in THF afforded polymers having a partially different structure from a vinyl polymer based on the ${ }^{1} \mathrm{H}$ and ${ }^{13} \mathrm{C}$ NMR analyses. The ${ }^{1} \mathrm{H}$ and ${ }^{13} \mathrm{C}$ NMR spectra of the polymer obtained from 2 with $n$-BuLi in THF are shown in Figures $2 b$ and 3c, respectively. Some undefined peaks that are not assigned to a normal vinyl polymer are observed, although these polymers were fully soluble in $\mathrm{CHCl}_{3}$ and THF. Figure 4 shows UV absorption spectra of the poly $(2)$ s obtained by anionic and radical methods. The intensity of absorption at $240 \mathrm{~nm}$ (phenylacetylene moiety) decreased and the absorption shifted to longer wavelengths in the spectra of the polymers obtained radically and anionically in THF due to conjugation structures. The polymerization may partly proceed through an intramolecular cyclization reaction. The total structure of the polymer obtained in THF had
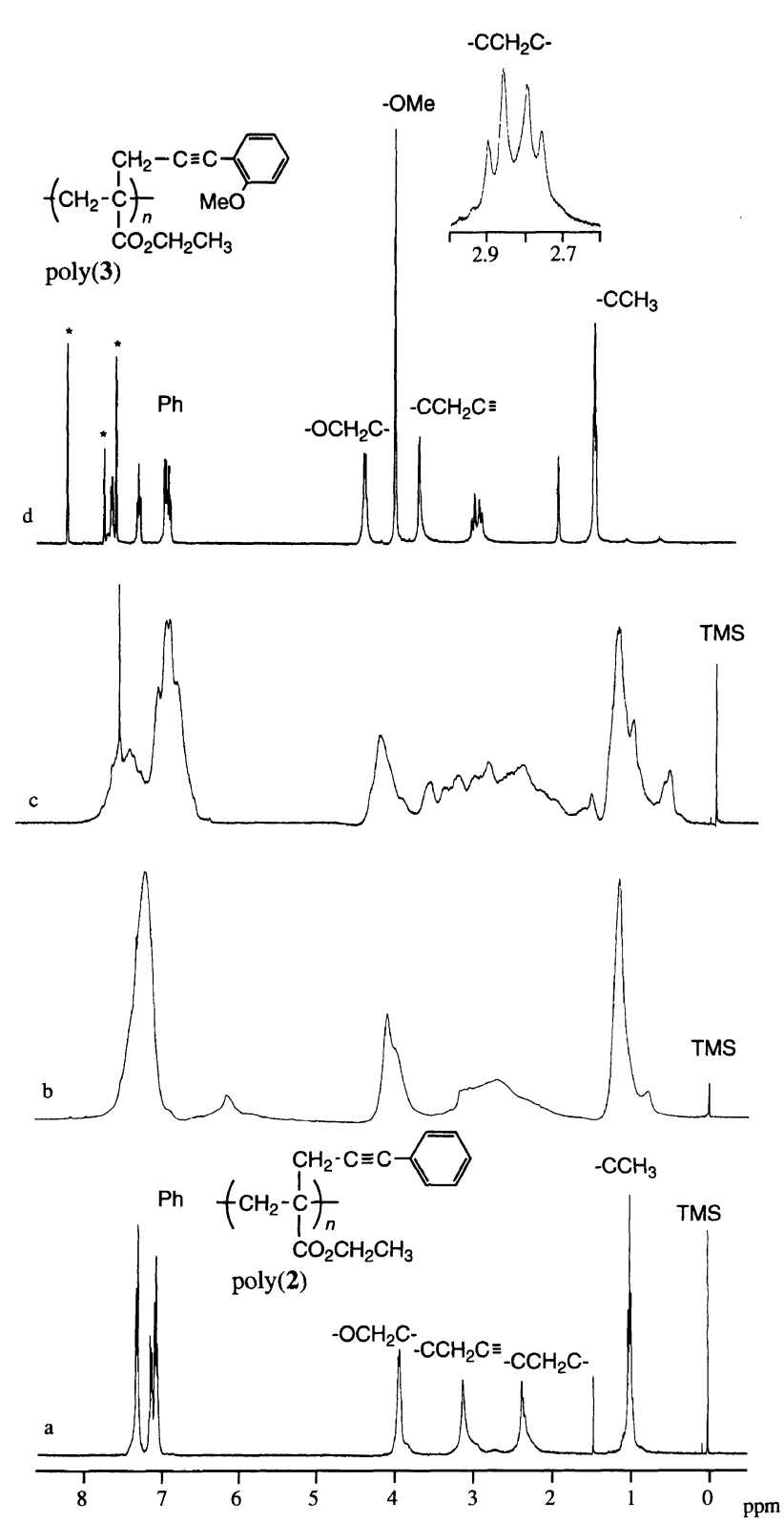

Figure 2. ${ }^{1} \mathrm{H}$ NMR spectra of poly $(2)$ s obtained with $n$-BuLi in toluene (entry 4) (a), in THF (entry 5) (b), with AIBN (entry 6) (c) (measured in $\mathrm{CDCl}_{3}$ at $60^{\circ} \mathrm{C}$ ), and poly $(3)$ obtained with $n$-BuLi in toluene (entry 7) (d) (measured in nitrobenzene- $d_{5}$ at $150^{\circ} \mathrm{C},{ }^{*}$ donates a peak of nitrobenzene). 
not yet been determined. The bulkiness of the substituent of an acetylenic group seems to affect the reactivity
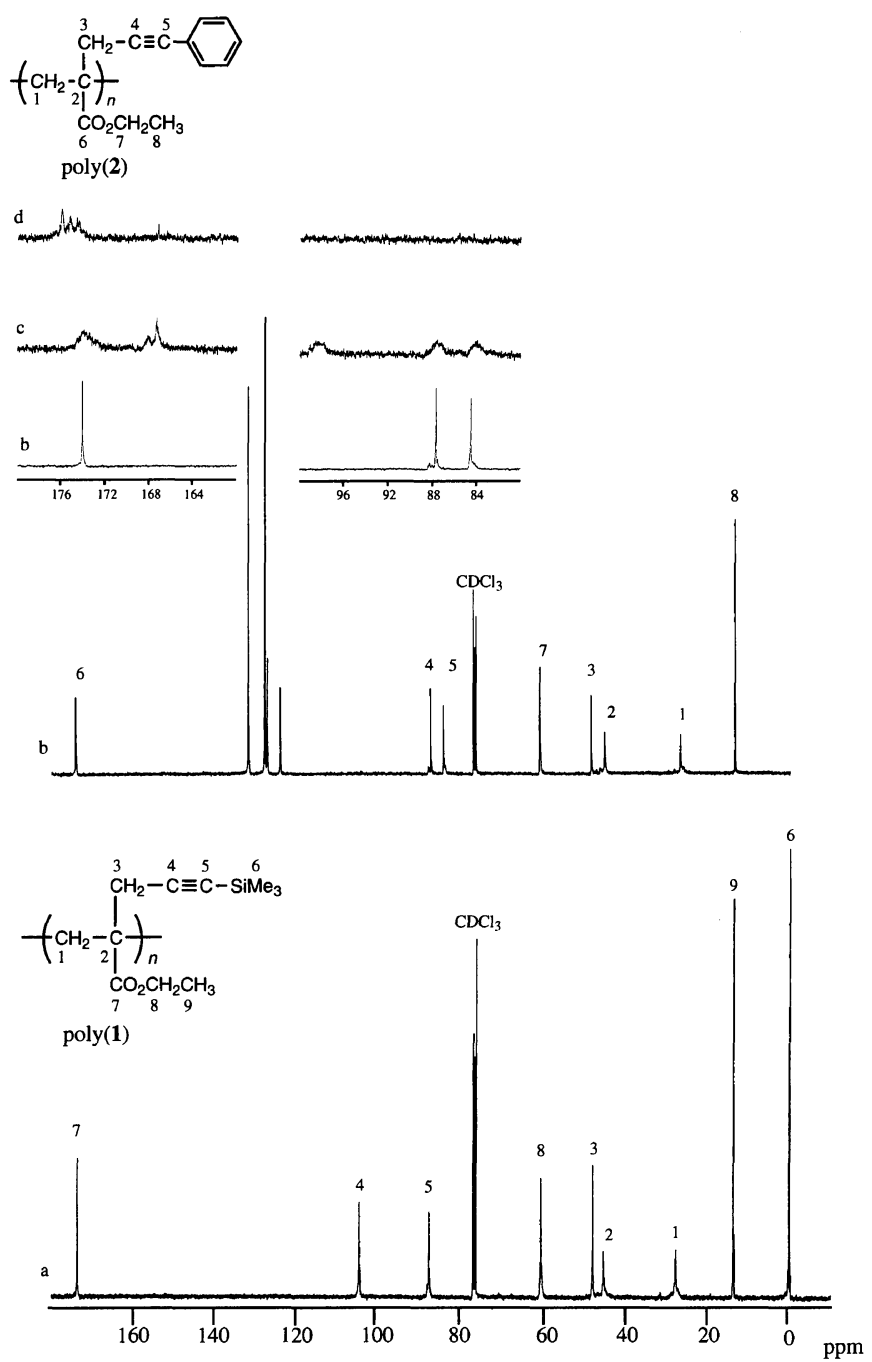

Figure 3. ${ }^{13} \mathrm{C}$ NMR spectra of poly(1) obtained with $n$-BuLi in toluene (a), poly(2)s obtained with $n$-BuLi in toluene (entry 4) (b), in THF (entry 5) (c), and with AIBN (entry 6) (d) (measured in $\mathrm{CDCl}_{3}$ at $60^{\circ} \mathrm{C}$ ). of the $\mathrm{C}-\mathrm{C}$ triple bond during the anionic polymerization in THF. The bulkier substituents, such as the trimethylsilyl, tert-butyl, and $N, N$-dimethylamino groups, may prevent the addition of the propagating anion to the acetylenic groups.

The radical polymerization of $\mathbf{1}-\mathbf{6}$ with $2,2^{\prime}$ azobisisobutyronitrile (AIBN) at $60^{\circ} \mathrm{C}$ resulted in no or poor yields to afford polymers with a low molecular weight. The structure of the polymers obtained by the radical method was significantly different from that of the polymers obtained by the anionic method (Figures 2 c, $3 \mathrm{~d}$, and $4 \mathrm{c}$ ). The radically obtained polymers in these experiments were soluble in $\mathrm{CHCl}_{3}$ and THF. The peaks for the pendant acetylenic group almost disappeared and some alkene carbons peaks were observed in the ${ }^{13} \mathrm{C}$ NMR spectrum (Figure 3d). The UV absorption intensity at the longer wavelength bands increased in comparison with that of the polymer obtained by the anionic polymerization in THF. The radical polymerization may proceed through the cyclopolymerization and the some of expected repeating units is shown in Scheme 1. However, the total structure of the polymer prepared by the radical method is not clear at present.

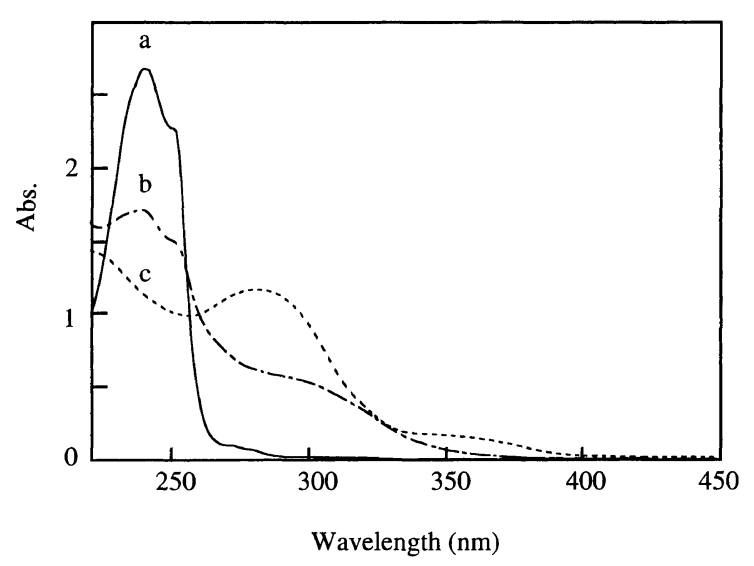

Figure 4. UV spectra of poly $(2)$ s obtained with $n$-BuLi in toluene (entry 4) (a), in THF (entry 5) (b), and with AIBN (entry 6) (c) (c= $3.3 \mathrm{mg} \mathrm{mL}^{-1}$, THF, [cell length] $=0.1 \mathrm{~mm}$ ).

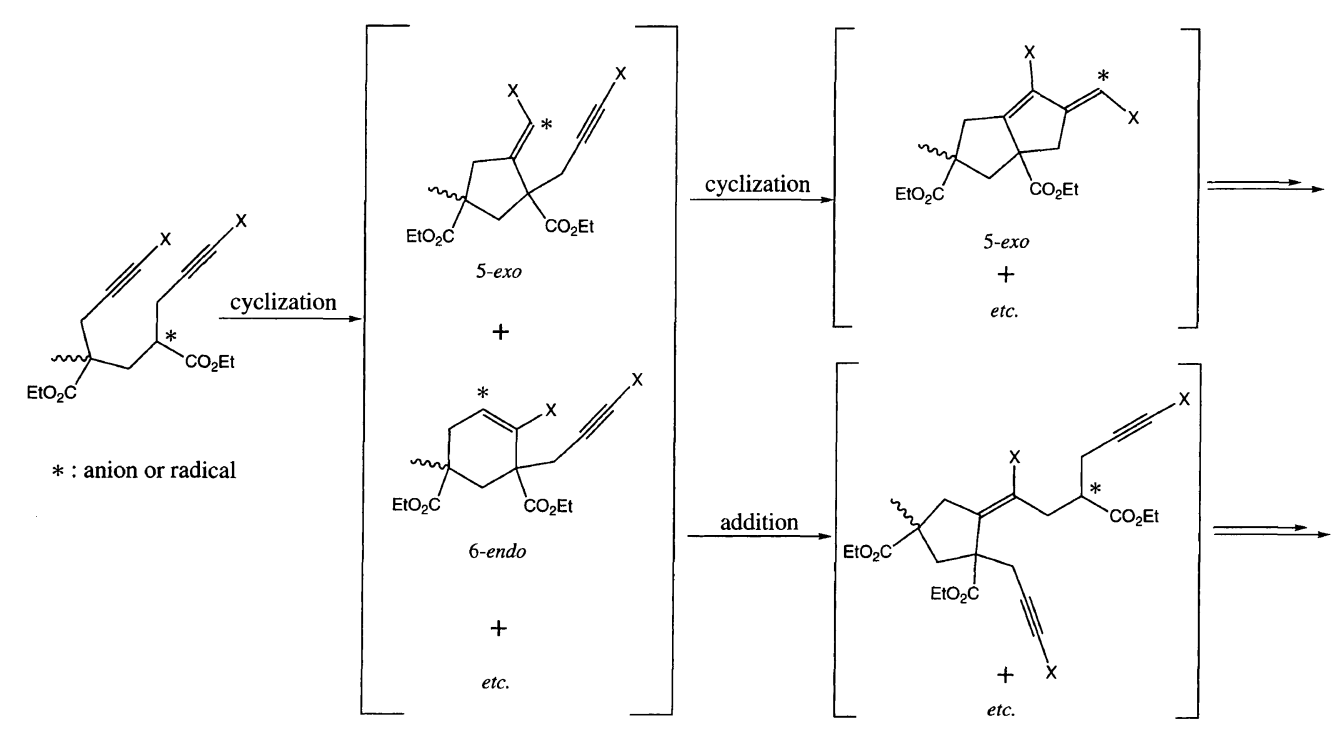

Scheme 1. 
Poly(1) has a silyl group which is easily removed by treatment with tetrabutylammonium fluoride (TBAF). $\operatorname{Poly}(1)$ was quantitatively converted into poly[ethyl $\alpha$ (propargyl)acrylate] (poly(7)) (Scheme 2). Figure 1c dem-

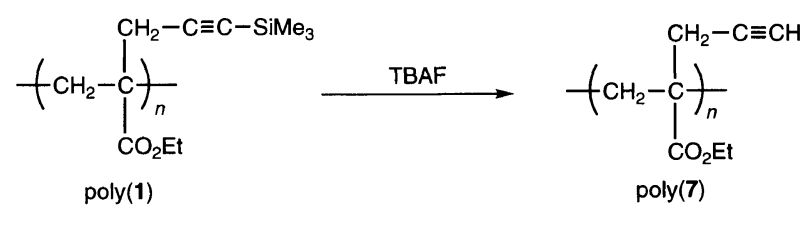

Scheme 2.
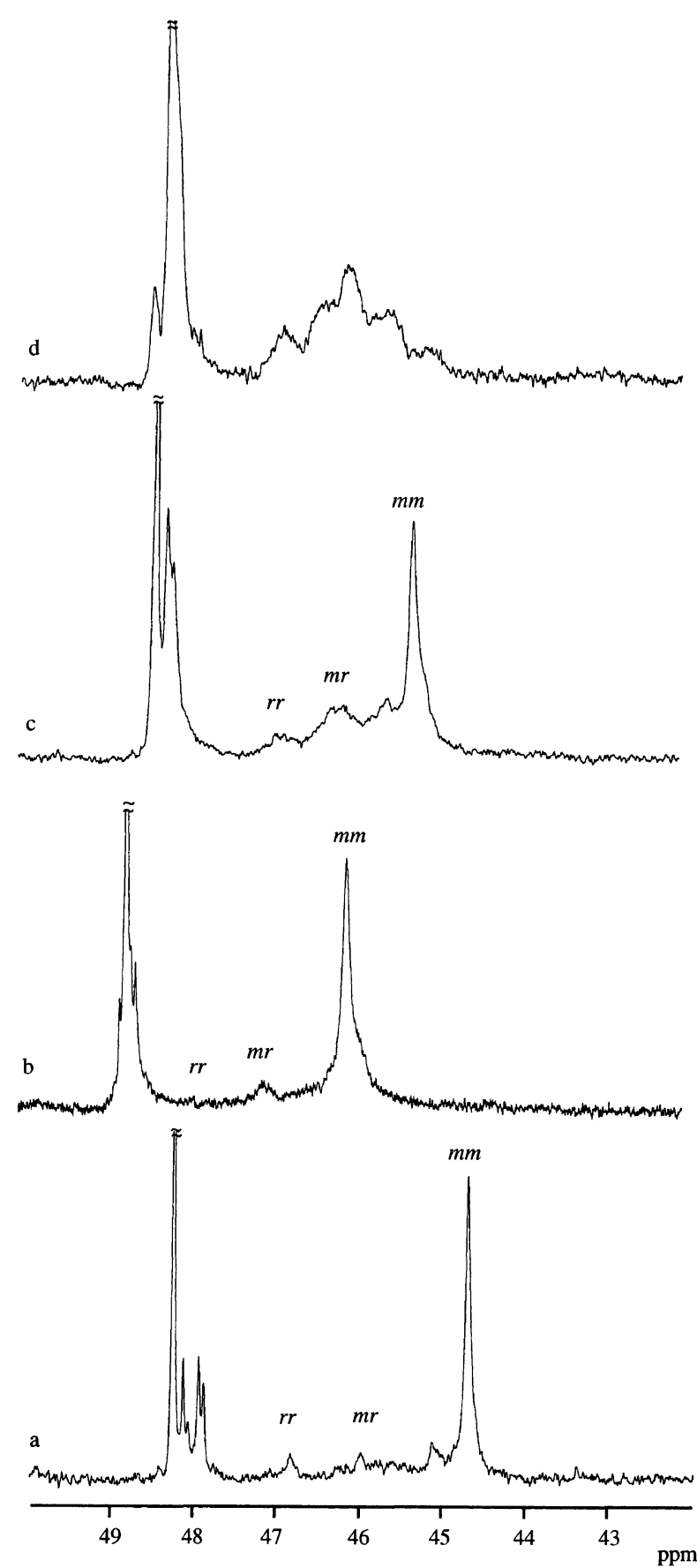

Figure 5. ${ }^{13} \mathrm{C}$ NMR spectra of main chain quaternary carbons in poly(7) (a), poly(3) (entry 7) (b), poly(5) obtained with $n$-BuLi in toluene (entry 11) (c), and poly(5) obtained with $\mathrm{Ph}_{2} \mathrm{NLi}$-TMEDA (entry 12) (d) (measured in $\mathrm{CDCl}_{3}$ at $60^{\circ} \mathrm{C}$ ). onstrates the ${ }^{1} \mathrm{H}$ NMR spectrum of $\operatorname{poly}(7)$ derived from poly $(\mathbf{1})$ obtained with $n$-BuLi in toluene. The trimethylsilyl group was completely removed and the generation of a new acetylenic proton at $2.03 \mathrm{ppm}$ was observed. $\operatorname{Poly}(\mathbf{7})$ having a more reactive terminal acetylene may be readily converted into the other functional polymers. The ${ }^{1} \mathrm{H}$ NMR spectral pattern of the main chain methylene protons $(2.15-2.25 \mathrm{ppm})$ of poly $(7)$ exhibits a typical $\mathrm{AB}$ quartet with a coupling constant of $6.8 \mathrm{~Hz}$ as shown in an expanded spectrum. This observation indicates that an isotactic polymer was produced in the polymerization of 1 with $n$-BuLi in toluene at $-78^{\circ} \mathrm{C}$.

The ${ }^{13} \mathrm{C}$ NMR spectra of the main chain quaternary carbon in the anionically obtained polymers in toluene are shown in Figure 5. The peaks seem to exhibit a splitting due to triad sequences and are assigned to $\mathrm{mm}, \mathrm{mr}$, and $r r$ from the high magnetic field as shown in figure. The tacticity of the poly $(7)$ was estimated as $85: 11: 4$ ( $m m: m r: r r$ ), whose value is good agreement with that evaluated form ${ }^{1} \mathrm{H}$ NMR analysis (Figure 5a). The evaluated triad tacticities of the polymers obtained with $n$ BuLi are summarized in Table II. The polymers obtained in toluene were rich in isotacticity $(\mathrm{mm}>68 \%)$, whereas the polymerizations in THF gave polymers with a low stereoregularity. The isotacticity of the obtained polymers seems to increase with the increasing bulkiness of the acetylenic group substituent. The polymer obtained from the anionic polymerization of 3 , having an ether group at the ortho-position of the phenyl ring, with $n$-BuLi in toluene at $-78^{\circ} \mathrm{C}$ (entry 7 , Table I) showed the highest isotacticity, estimated to be 89:9:2 ( $\mathrm{mm}: \mathrm{mr}$ : $r r$ ) (Figure 5b), which is much higher than that of poly(2) anionically prepared in toluene $(73: 18: 9)$. The ${ }^{1} \mathrm{H}$ NMR spectrum of the main chain methylene proton (2.6 -3.0 ppm) showed a typical $\mathrm{AB}$ quartet with a coupling constant of $15.2 \mathrm{~Hz}$ (Figure 2d), supporting the fact that the anionically obtained poly $(3)$ in toluene is rich in isotacticity. The introduction of the ether group at the ortho-position of the phenyl group significantly affects the stereocontrol of the anionic polymerization. The stereoregularity of the polymer may be controlled by the intra- and intermolecular coordination of the polar groups on the growing polymer chain end and monomers to the countercation $\left(\mathrm{Li}^{+}\right)$as previously reported for the anionic polymerization of $\alpha$-(alkoxymethyl)- and $\alpha$ (aminomethyl)acrylates. ${ }^{4,5,8}$ On the other hand, the polar groups such as the methoxymethyl and aminomethyl

Table II. Triad tacticity of the polymers obtained with $n$-BuLi

\begin{tabular}{llll}
\multicolumn{1}{c}{$\mathrm{X}$} & & at $-78^{\circ} \mathrm{C}$ & \\
\hline $\mathrm{SiMe}_{3}$ & $(\mathbf{1})$ & Solvent & $\mathrm{mm} / \mathrm{mr} / \mathrm{rr}^{\mathrm{a}}$ \\
& & Toluene & $85 / 11 / 4^{\mathrm{b}}$ \\
$\mathrm{Ph}$ & $(\mathbf{2})$ & THF & Toluene \\
$o-\mathrm{MeOPh}$ & $(\mathbf{3})$ & Toluene & $73 / 18 / 9$ \\
$t-\mathrm{Bu}$ & $(\mathbf{4})$ & Toluene & $89 / 9 / 2$ \\
& & THF & $75 / 25^{\mathrm{d}}$ \\
$\mathrm{CH}_{2} \mathrm{OMe}^{\mathrm{C}}$ & $(\mathbf{5})$ & Toluene & $45 / 40 / 15$ \\
$\mathrm{CH}_{2} \mathrm{NMe}_{2}$ & $(\mathbf{6})$ & Toluene & $68 / 24 / 8$ \\
& & THF & $73 / 19 / 8$ \\
& & & $25 / 50 / 25$
\end{tabular}

${ }^{\mathrm{a}}$ Estimated by ${ }^{13} \mathrm{C}$ NMR analysis of main chain quaternary carbon. ${ }^{\mathrm{b}}$ Estimated from the signals of poly $(\mathbf{7}) .{ }^{\mathrm{c}}$ Not determined. d The $m r$ amd $r r$ peaks were not clearly separated. 
groups attached direct to the acetylenic moieties in $\mathbf{5}$ and 6 may not allow the appropriate chelation with the countercation at the propagation end to afford the polymer with stereoregularity. The poly(5) obtained with the $\mathrm{Ph}_{2} \mathrm{NLi}-N, N, N^{\prime},-N^{\prime}$, -tetramethylethylenediamine (TMEDA) complex in toluene fairly decreased in the isotactic content ( $m m: m r: r r \approx 37: 50: 13$ ) as shown in Figure $5 \mathrm{~d}$. The initiators also have a significant effect on the tacticity.

In conclusion, novel monomers, $\alpha$-(propargyl)acrylate derivatives $(\mathbf{1}-\mathbf{6})$, were polymerized with $n$-BuLi in toluene to provide normal vinyl polymers rich in isotacticity (up to $\mathrm{mm}=89 \%$ ). The polymerization conditions such as initiators and solvents significantly affected the structure and the stereoregularity of the obtained polymer. Poly(1) was readily converted into poly(7) as a novel reactive and functional polymer.

Acknowledgment. This work was partially supported by a Grant-in-Aid for Scientific Research (No.11450355) from the Ministry of Education, Science, Sports, and Culture of Japan and by CREST (Core Research for Evolutional Science and Technology) of Japan Science and Technology Corporation (JST).

\section{REFERENCES}

1. For example, see: a) H. Yuki and K. Hatada, Adv. Polym. Sci., 31, 1 (1979). b) B. Yamada and S. Kobatake, Prog. Polym. Sci., 19, 1089 (1994). c) G. R. Dever, F. E. Karasz, W. J. Macknight, and R. W. Lenz, J. Polym. Sci., Polym. Chem. Ed., 13, 2151 (1975). d) K. G. Saunders, W. I. MacKnight, and R. W. Lenz, Macromolecules, 15, 1 (1982). e) J. S. Roman, E. L. Madruga, and M. A. Lavia, Macromolecules, 17, 1762 (1984). f) T. Sato, N. Morita, H. Tanaka, and T. Ota, Makromol. Chem., 191, 2599 (1990).

2. K. Chikanishi and T. Turuta, Makromol. Chem., 81, 198 (1965).

3. a) H. Yuki, K. Hatada, T. Niinomi, and K. Miyaji, Polym. J., 1, 130 (1970). b) K. Hatada, S. Kokan, T. Niinomi, K. Miyaji, and H. Yuki, J. Polym. Sci., Polym. Chem. Ed., 13, 2117 (1975).

4. S. Habaue, H. Yamada, T. Uno, and Y. Okamoto, J. Polym. Sci., Part A: Polym. Chem., 35, 721 (1997).

5. S. Habaue, T. Uno, H. Baraki, and Y. Okamoto, Polym. J., 29, 983 (1997).

6. J. Villieras and M. Rambaud, Synthesis, 924 (1982).

7. The hexane insoluble polymers were collected after extraction with $\mathrm{CHCl}_{3}-\mathrm{H}_{2} \mathrm{O}$ system

8. S. Habaue, H. Baraki, T. Shibagaki, and Y. Okamoto, Polym. J., 32, 173 (2000). 